\title{
Malignant And Benign Lesions of The Eyelid- A is topathological Study of 78 Patients in Bundelkhand Region.
}

\author{
Jitendra kumar ${ }^{1}$,Arun Kumar Pathak ${ }^{2}$, Amit Verma $^{3}$,Shweta Dwivedi ${ }^{4}$ \\ ${ }^{1}$ (Associate Professor And Head Department Of Ophthalmology, Mlb Medical College Jhansi U.P., India) \\ ${ }_{2}^{2}$ (Junior Resident Department Of Ophthalmology, Mlb Medical College Jhansi U.P., India) \\ ${ }^{3}$ (Junior Resident Department Of Ophthalmology, Mlb Medical College Jhansi \\ U.P., India) \\ ${ }^{4}$ (Junior Resident Department Of Ophthalmology, Mlb Medical College Jhansi U.P., India)
}

\begin{abstract}
We carried out the study to assess the incidence of eyelid neoplasms with respect to age, sex, location and histopathological type. We done a retrospective study and studied 78 cases of eye lid tumours from aug. 2014 to dec.2016, through histopathological confirmation.

A total of 130 cases of ocular neoplasms were seen, among which eyelid tumours accounted the maximum with 78 cases (60\%). The most common age group affected was between 51-60 yrs (23.25\%). Benign tumours accounted for $42(53.8 \%)$ cases and malignant tumours were encounted in 36(46.1\%) cases. Among the benign tumours capillary hemangioma was the commonest tumour with 13 cases. Sebaseous cell carcinoma was commonest malignant tumour seen in 16(44.4\%) cases followed by basal cell carcinoma 11 cases(30.5\%) and squamous cell carcinoma in 7(19.4\%) cases. Few rare tumours like mucinous eccrine carcinoma, basal cell carcinoma with angiosarcoma were also seen.

Benign and malignant tumours were seen almost equally with sebaceous cell carcinoma been the most common malignant tumour similar to that seen various studies conducted in India, though basal cell carcinoma is the most common malignant eyelid tumour worldwide. This variation might be due to geographical and environmental factors.
\end{abstract}

Keywords: Eyelid, malignant tumours, sebaceous cell carcinoma

\section{Introduction}

Eyelid lesions are common concerns amongst patients. Internists, family practitioners, dermatologists, and ophthalmologists are often requested to determine if a lesion is benign or malignant. Eye lid tumours estimated to represent more than $90 \%$ of all ophthalmic tumours ${ }^{[1]}$. The classification and differentiation in type of eyelid tumour are beneficial to histopathological diagnosis ${ }^{[2]}$. Benign tumors are more than malignant tumors ${ }^{[3]}$. The treatment depends on the invasiveness of the cancer which in turn depends on the type of malignancy ${ }^{[4]}$. Basal cell carcinoma has a better prognosis and sebaceous gland carcinoma has a higher mortality and therefore should be treated much more aggressively. Long-term follow-up is needed after treatment of malignant eyelid tumours ${ }^{[5]}$.

\section{Material And Methods}

We have done a retrospective analysis of 78 eyelid tumours by histopathological confirmation. Standard protocol was followed for processing of ocular tissues. Routine Hematoxylin and Eosin staining was done. Special stains like Alcian blue, PAS \& Reticulin stain were done wherever necessary. We analysed the age and sex distribution of lesions, location and histopathological result of the tumours.

\section{Results}

From aug.2014 to dec.2016, a total of 78 cases of eyelid tumours with histopathological confirmation were analysed retrospectively, out of which $42(53.8 \%)$ cases were benign and 36(46.2\%) cases were malignant. Both benign and malignant tumours were seen more on the upper lid. No cases were seen below $10 \mathrm{yrs}$ and most common age group affected was between 51-60 years $(23.25 \%$ ) (Table 1)

Among the benign tumors, capillary haemangioma was the commonest lesion accounting for 13 cases(30.9\%) followed by naevus 8 cases, seborric keratosis 5 cases, lipoma 4 cases, lipogranuloma 4 cases, cutaneous myxoma 3 cases, cavernous haemangioma 3 cases, clear cell hidradennoma 2 cases .(Table 2)

Among the malignant ones, sebaceous cell carcinoma was the most common which was seen in 16(44.4\%) cases, followed by basal cell carcinoma 11(30.5\%), squamous cell carcinoma 7 cases(19.4\%) and single cases of mucinous eccrine carcinoma, basal cell carcinoma with angiosarcoma, (Table 3). 
Median age at diagnosis of malignant lesion was 62 years. Sebaceous cell carcinoma was found most commonly on upper eyelid accounting for 12cases out of 18 cases $(66.6 \%)$, showed a female preponderance, $88 \%$ of cases presenting after 60 years. while basal call carcinoma(66.6\%) and squamous cell carcinoma $(57.1 \%)$ were found commonly on lower lid.

\section{Discussion}

Malignancies of the eyelid are predominantly cancers of the skin. As with other skin tumours, malignant lesions of the eyelid increases with age Mihaela- cristiana caloi et al ${ }^{[6]}$ studied 471 cases of eyelid tumours and found 114 pseudotumours, 102 benign tumours and 225 cases of malignant tumours. Fouzia farat et $\mathrm{al}^{[7]}$ studied 288 cases of eyelid lesions and found 105 cases $(44.11 \%)$ of benign, $87(36.99 \%)$ cases malignant, $39(16.39 \%)$ cases of non neoplastic tumour like lesions and 7(2.94\%) cases were pre-malignant lesions. Deprez et $\mathrm{al}^{[8]}$ studied 5504 cases over a period of 19 years and found $84 \%$ of benign tumours and rest malignant. The majority of eyelid lesions were benign eyelid tumors while malignant eyelid tumors contributed $10.8 \%$ of the total eyelid lesions. Of the eyelid lesions $24.1 \%$ were malignant and $75.9 \%$ were benign ${ }^{[10]}$. In the present study, for all the eyelid tumours we analysed, benign tumours were 42 cases representing $53.8 \%$ and 36 malignant tumours representing $46.2 \%$. Fouzia Farhat et $\mathrm{al}^{[7]}$ found epidermal inclusion cyst $(26.6 \%)$ to be the commonest of benign tumors followed by dermoid cyst(21.90\%). The most common benign lesions were seborrheic keratosis (19.7\%), followed by lipogranuloma (13.7\%), intradermal nevus (12.2\%), and hidrocystoma and fibroepithelial polyps (each with $8.6 \%$ ).In our study it was capillary haemangioma(13 cases)

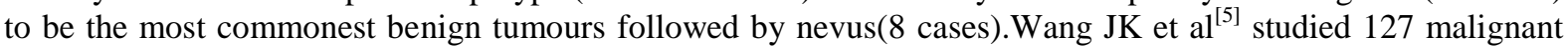
eyelid tumours, found 79 basal cell carcinoma(62.2\%), 30 sebaceous cell carcinoma(23.6\%), 11 squamous cell carcinoma(8.7\%), 5 malignant melanoma(3.9\%), one kaposi's sarcoma( $0.8 \%$ ) and one metastatic carcinoma $(0.8 \%)$. All malignant lesions were more common in the lower lid than the upper lid. The mean age at diagnosis for all malignant tumours was 62.6 years.Basal cell carcinoma was the most frequent malignant neoplasm and represented $82.2 \%$ from all malignant eyelid tumors. The maximum incidence of lesions was in 5 th and 6th decade and the common location was the lower lid. The most common eyelid malignancy was basal cell carcinoma $(71.8 \%)$, followed by squamous cell carcinoma $(9.7 \%)$, melanoma $(9.2 \%)$, and sebaceous cell carcinoma $(7.3 \%)$. The most common primary malignancy was basal cell carcinoma(84\%) followed by sebaceous adenocarcinoma(10.2\%) and squamous cell carcinoma(3.4\%).Basal cell carcinoma was the frequent malignant tumor( $86 \%)$ followed by squamous cell carcinoma(7\%) and sebaceous carcinoma(3\%).Basal cell carcinoma is the most common malignant eyelid tumor in whites. The lower eyelid and medial canthus are the most frequent sites of origin.Fouzia Farhat et $\mathrm{al}^{[7]}$ also found basal cell carcinoma with 49 cases $(56.32 \%)$ to be the commonest followed by squamous cell carcinoma in 18 cases(20.69\%), sebaceous cell carcinoma in 13 cases $(14.94 \%)$ along with few rare tumors.Squamous cell carcinoma was the most frequently encountered malignant tumor of the eyelid seen in this series.Sebaceous gland carcinoma was the commonest (40.5 per cent) finding, followed by squamous cell carcinoma (27 per cent), basal cell carcinoma ( 24.3 per cent), basosquamous carcinoma (5.4 per cent) and malignant melanoma $(2.7 \text { per cent })^{[13]}$.

Although basal cell carcinoma is the most common eyelid cancer in Taiwan, sebaceous gland carcinoma is also common.Malignant tumors of the eyelid other than basal cell and squamous cell carcinoma are uncommon and usually occur in elderly white persons. Primary eyelid tumors of any type are rare in blacks. The risk of a non-basal cell and non-squamous cell malignant neoplasm of the eyelid in Florida is 6.4 times greater for whites than for blacks. A variety of B-cell lymphomas can be manifested as primary eyelid tumors ${ }^{[14]}$.

Basal cell carcinoma was the most common malignant eyelid tumour in north-west Pakistan, followed by squamous cell carcinoma. In contrast, the sebaceous gland carcinoma was the least common in the study population.In the present study it was the sebaceous cell carcinoma which was the commonest malignant tumour with its incidence more on the upper lid. A racial difference in the incidence of basal cell carcinoma, sebaceous gland carcinoma, and squamous cell carcinoma can be considered in making a diagnosis ${ }^{[16]}$.

Tables

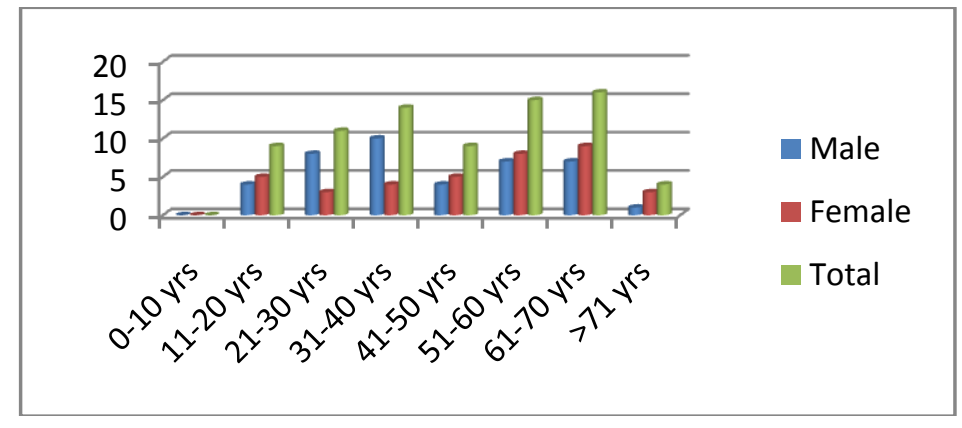


Table 2: Benign Tumors

\begin{tabular}{|l|l|l|}
\hline Diagnosis & Number & Percentage \\
\hline Capillary Hemangioma & 13 & $30.9 \%$ \\
\hline Nevus & 08 & $19.04 \%$ \\
\hline Seborric Keratosis & 05 & $11.9 \%$ \\
\hline Lipoma & 04 & $9.5 \%$ \\
\hline Lipogranuloma & 04 & $9.5 \%$ \\
\hline Cutaneous Myxoma & 03 & $7.1 \%$ \\
\hline Cavernous Hemangioma & 03 & $7.1 \%$ \\
\hline Clear Cell Hidradenoma & 02 & $4.7 \%$ \\
\hline Total & $\mathbf{4 2}$ & $\mathbf{1 0 0 \%}$ \\
\hline
\end{tabular}

Table 3: Malignant Tumors

\begin{tabular}{|l|l|l|l|l|}
\hline Diagnosis & Upper Lid & Lower Lid & Total Number & Percentage \\
\hline $\begin{array}{l}\text { Sebaceous Cell } \\
\text { Carcinoma }\end{array}$ & 11 & 05 & 16 & $44.4 \%$ \\
\hline $\begin{array}{l}\text { Basal Cell } \\
\text { Carcinoma }\end{array}$ & 03 & 08 & 11 & $30.5 \%$ \\
\hline $\begin{array}{l}\text { Squamous Cell } \\
\text { Carcinoma }\end{array}$ & 03 & 04 & 07 & $19.4 \%$ \\
\hline $\begin{array}{l}\text { Mucinous Eccrine } \\
\text { Carcinoma }\end{array}$ & 1 & - & 1 & $2.8 \%$ \\
\hline $\begin{array}{l}\text { Basal Cell } \\
\text { Carcinoma With } \\
\text { Angiosarcoma }\end{array}$ & 1 & - & 1 & $2.8 \%$ \\
\hline Total & 20 & 16 & 36 & $100 \%$ \\
\hline
\end{tabular}

\section{Conclusion}

Eyelid is a heterogeneous tissue, hence we tend to see a variety of tumoral types \& subtypes, both benign \& malignant. Though basal cell carcinoma is the most common tumour of the eyelid worldwide, sebaceous cell carcinoma was the commonest malignant tumour in the present study co- relating with the other Indian studies. This emphasises the environmental \& geographic factors in the occurrence of malignant eyelid tumours.

\section{Refrences}

[1]. Lee SB, Saw SM, Eong KGA, Chan TK, Lee HP. Incidence of eyelid cancers in Singapore from 1968 to 1995. Br J Ophthalmol 1999; 83: 595-597.

[2]. Ni Z. Histopathological classification of 3,510 cases with eyelid tumor. Zhonghua Yan Ke Za Zhi 1996; 32: 435-437

[3]. Lin HY, Cheng CY, Hsu WM, Kao WH, Chou P. Incidence of eyelid cancers in Taiwan: a 21 -year review. Ophthalmology. Nov 2006;113(11):2101-7.

[4]. Jahagirdar SS, Thakre TP, Kale SM, Kulkarni H, Mamtani M.A clinicopathological study of eyelid malignancies from central India. Indian J Ophthalmol. 2007MarApr;55(2):109-112.

[5]. Wang JK, Liao SL, Jou JR, Lai PC, Kao SC, Hou PK, Chen MS. Malignant eyelid tumours in Taiwan. Eye 2003; 17: $216-220$.

[6]. Mihaela- Cristiana Coroi, Elena Ro Ca, Gabriela Mu.Iu, T. Coroi, Marinela Bonta. Eyelid tumors: histopathological and clinical study performed in County Hospital of Oradea between 2000.2007. Romanian Journal of Morphology and Embryology 2010, 51(1): 111.115

[7]. Fouzia Farhat, Qamar Jamal, Mahmood Saeed, Zia Ghaffar. Evaluation of Eyelid Lesions at a Tertiary Care Hospital, Jinnah Postgraduate Medical Centre (JPMC), Karachi. Pak J Ophthalmol 2010, Vol. 26 No. 2

[8]. Deprez M, Uffer S. Clinicopathological features of eyelid skin tumors. A retrospective study of 5504 cases and review of literature. Am J Dermatopathol. May 2009;31(3):256-262.

[9]. Pornpanich K, Chindasub P. Eyelid tumors in Siriraj hospital from 2000-2004. J Med Assoc Thai 2005; 88 (Suppl 9): S11-S14.

[10]. Sean Paul, Dat T. Vo, Rona Z. Silkiss,Malignant and Benign Eyelid Lesions in San Francisco: Study of a Diverse Urban Population. American Journal of Clinical Medicine. Winter 2011 • Volume Eight, Number One: 40-46.

[11]. Cook BE Jr, Bartley GB. Epidemiologic characteristics and clinical course of patients with malignant eyelid tumors in an incidence cohort in Olmsted County, Minnesota. Ophthalmology. 1999 Apr;106(4):746-50.

[12]. Abe M, Ohnishi Y, Hara Y, Shinoda Y, Jingu K.Malignant tumor of the eyelid--clinical survey during 22-year period. Jpn J Ophthalmol. 1983;27(1):175-84.

[13]. Kumar, R. (2010), Clinicopathologic study of malignant eyelid tumours. Clinical and Experimental Optometry, 93: 224-227. doi: $10.1111 / \mathrm{j} .1444-0938.2010$.

[14]. Margo CE, Mulla ZD. Malignant tumors of the eyelid: a population-based study of non-basal cell and non-squamous cell malignant neoplasms. Arch Ophthalmol. 1998 Feb;116(2):195-8.

[15]. Ibrar Hussain, Fida Mohammad Khan, Mumtaz Alam, Bakht Samar Khan. Clinicopathological Analysis of Malignant Eyelid Tumours in north-west Pakistan. JPMA 63: 25; 2013

[16]. Takamura H, Yamashita H. Clinicopathological analysis of malignant eyelid tumor cases at Yamagata university hospital: statistical comparison of tumor incidence in Japan and in other countries. Jpn J Ophthalmol. 2005 Sep-Oct;49(5):349-54. 